there is not a great deal of discussion of the nuances of the growth debate. It does not explore, for example, whether environmental problems are an inevitable product of any growth or simply a product of the current, business friendly policy environment. Might it be possible to have infinite growth over time, if the growth rate remains low every year? What kind of growth are we talking about-throughput or output?

The book can, at times, roam from what most people would take to be its central theme, wandering into ground fairly well travelled by authors like David Harvey and David Kotz in criticizing neoliberal policies. While most of the time the link between this policy environment and the quest for growth is clear, it does throw up a few inconsistencies. For example, Higgs provides evidence that the liberalization of trade and finance has been accompanied by lower rates of economic growth. Higgs is clearly opposed to liberalization. Yet, since economic growth is the problem, should liberalization not be supported, despite the fact that its impact is the opposite of that which is intended? This is not to say that Collision Course is not a worthwhile read. It most definitely is, especially if the reader is looking for something along the lines of "capitalism against nature" or perhaps even "capitalism against humanity."

Ian Hudson

University of Manitoba

\title{
Eric Hazan, A History of the Barricade (London and New York: Verso, 2015). 144pp. Hardcover \$17.95.
}

Eric Hazan's brief A History of the Barricade provides an eminently readable account of the revolutionary barricade. Much more than a mere defensive tactic, Hazan shows how the barricade functions as a call to arms, a communication network, a theatrical scene, and an offensive maneuver that can divide superior forces, pin them down, and impel them into submission. As one might expect, the majority of the book focuses on nineteenth-century Paris, the revolutionary city par excellence. More surprisingly, however, it begins with three chapters on earlier barricades in Paris in May 1588, August 1648, and May 1795. It also provides an engaging description of the barricades used in 1827, the "prelude" to the Revolution of 1830 , as well as an excellent look at how the barricade was "exported" into Europe during the 1848 "Spring of Nations."

Methodologically, the book is classic Hazan, intermixing memoirs and letters of famous writers and artists from Victor Hugo to Richard Wagner, reports from military leaders such as General Kilmaine, who directed the repression of the sans-culottes revolt of 1795, and archival material from unknown actors of insurrection, such as Charles Jeanne, who led the resistance during the republican uprising of 1832. Interestingly, there is scarcely any theoretical material from more well- 
known revolutionaries such as Auguste Blanqui, Karl Marx, or Friedrich Engels. Other familiar revolutionary figures such as Mikhail Bakunin only appear as witnesses to the barricades. Hazan thus shows his populist bent by utilizing his myriad sources to illustrate how the creation of barricades was nearly always a spontaneous act by the people. Whereas most social histories get bogged down through excessive detail, the success of Hazan's work stems from his intimate knowledge of revolutionary history, which allows him to seize effortlessly the essential elements of each of the key moments where the barricade was employed, and crystallize them with the perfect citation. This enables the voices from either side of the barricades to reach through the chaos of the many events he discusses. A History of the Barricade thus treats us to a brilliant series of vignettes of popular ingenuity.

The weakest chapter is surely the last, when Hazan discusses the barricades of the Paris Commune. The recapture of Paris by the troops of Versailles during the "Bloody Week" of May 21 to May 28 is described in detail. While the chapter is informative, it loses the narrative coherence and force of the previous chapters. Part of this loss is certainly due to the nature of the event, which saw the Versailles troops surrounding the city of Paris and simultaneously attacking from multiple points. However, Hazan succeeds in crafting a compelling narrative of equally chaotic events in previous chapters, such as the June uprising of Paris in 1848. On the Commune, though, his narrative stiffens, and the reader is left with the sense that this formal issue is related to the content of the chapter and the new status of the barricade that it describes. Hazan reminds us that during the Commune barricades were not an act of popular spontaneity, but were legislated into existence: the Commune established a "Barricades commission" in April 1871 headed by the shoemaker Napoléon Gaillard. They thus lose something of the mythical status that constituted their power in previous insurgencies: and also their military effectiveness, in Hazan's view. Indeed, he is very critical of the Communards' unpreparedness. For example, he mentions that on the day of the Versailles attack on May 21, the last parliamentary session of the Commune did not even bring up the question of defense; or that no one bothered to clean and ready the cannons of Montmartre since the beginning of the Commune on March 18. While these and other decisions undisputedly constituted military errors, it is unfortunate that Hazan's critical eye towards the leadership of the Commune seems to interfere with the narrative quality of the chapter.

The other criticism I have of the book is its decidedly Franco-centric (or Paris-centric) account of the barricade. With the exception of one chapter on the European barricades in 1848, all the other events take place in France, with most chapters focusing on Paris (only the Canut uprisings in Lyon in 1831 and 1834 constitute an exception). While the epilogue notes how barricades arose in many cities throughout the early twentieth century (Petrograd in 1917, Berlin in 1919, Barcelona in 1936 and Madrid in 1937), these events are not discussed. A more international approach would thus have been welcome. Of course, given the importance of bar- 
ricades in Parisian history, Hazan's choice to focus on the city is understandable, if not fully justified.

For Hazan, the last victorious barricades were in February 1848, with their role in insurrection declining from that point on. The book ends on an optimistic note, however. While the classical barricade's military role in insurrection may no longer be adequate to match state forces in contemporary cities, their symbolic role can be resurrected to significant effect, as in May 1968, when students used barricades to transform their student revolt into a revolutionary event by reaching back to the illustrious history of the barricade. Moreover, Hazan affirms that the principle function of the barricade, that of obstruction, is as relevant today as it was in previous periods, and new forms of barricades can be conceived to strategically block transportation, information, or energy flows. The final sentence of the book provides us with a synthesis of Hazan's anachronistic militancy, which locates the kernel of past revolutionary potential and brings it into today's conjuncture: "Future insurrections will rediscover, without knowing it, without saying it, and without paving-stones, the way of acting by stifling the power of the state that made the good old barricade so effective" (126). A History of the Barricade is essential reading for anyone seeking a guided tour of the barricades of revolutionary Paris. While it is certainly not the most in-depth account available of the many uprisings that it discusses, Hazan's book is arguably the most readable, and constitutes a marvelous introduction to the history of revolt.

Daniel Benson

New York University

\section{Margaret E. Boyle. Unruly Women: Performance, Penitence, and Punishment in Early Modern Spain (Toronto: University of Toronto Press, 2015). 184pp. Paperback \$26.95.}

One of the latest in a series of excellent University of Toronto Press books on the social and cultural context of early modern Spanish literature, Margaret E. Boyle's Unruly Women examines women's performance of penitence and rehabilitation both on the stages and in the correctional institutions of Madrid. In the late sixteenth and early seventeenth centuries, amid the Counter-Reformation, social change, and growing economic difficulty, Spaniards grew increasingly concerned about defending morality and preserving the social order. This concern particularly targeted women. As a result of economic crisis, growing numbers of women fell into poverty, were abandoned by husbands or fathers, became prostitutes or thieves, and otherwise engaged in acts that violated gender expectations as well as legal principles. Spaniards viewed these issues as moral concerns, and addressed them as such, through visible acts of punishment and penitence. Emphasizing these performative elements, Boyle shows that women's deviance was displayed and corrected on the 